\title{
Akıllı Şebeke Olgunluk Modelinin Dünya Çapındaki Uyarlamaları ve Türkiye İçin Öneriler Literatür Makalesi/Review Article
}

\author{
iD Fadime İLISULU ${ }^{1}$, (D) Ayça KOLUKISA TARHAN ${ }^{1}$, (D) Kubilay KAVAK ${ }^{2}$ \\ 1Bilgisayar Mühendisliği, Hacettepe Üniversitesi, Ankara, Türkiye \\ 2ESCARUS -TSKB Sürdürülebilirlik Danıșmanlığı A.Ș., İstanbul, Türkiye \\ fadimeilisulu@ hacettepe.edu.tr, atarhan@hacettepe.edu.tr, kavakk@escarus.com \\ (Geliş/Received:27.02.2019; Kabul/Accepted:08.02.2020)
}

DOI: $10.17671 /$ gazibtd.533221

\begin{abstract}
Özet- Elektriğe olan ihtiyacın sürekli artması ve teknolojinin ilerlemesiyle birlikte ülkeler, elektrik şebekesinde bilgi ve iletişim teknolojisini kullanan, aynı zamanda verimli ve güvenilir bir altyapı sunan akıllı şebekelere yönelmektedir. Ülkeler klasik şebekelerden akıllı şebekelere geçiş sürecinde hedeflerini belirlemek ve hedefleri gerçekleştirme sürecini yönetebilmek için stratejilere ve yol haritalarına ihtiyaç duymaktadır. Bu kapsamda bu ihtiyacı karşılamak, süreçlerin yönetimini kolaylaştırmak ve süreçleri iyileştirmek için alana özgü olgunluk modelleri kullanılmaktadır. Akıllı şebeke alanında ise 2011 yılında Akıllı Şebeke Olgunluk Modeli (Smart Grid Maturity Model - SGMM) yayınlanmıştır. SGMM, akıllı şebekelere geçişte hedeflerin ve bu hedeflere yönelik yol haritalarının oluşturulması, geçiş sürecinin yönetilmesi amacıyla bir kılavuz olarak hazırlanmıștır. Bazı ülkeler akıllı șebekeye geçiște bu modeli referans almaktadır. Ancak, literatürdeki çalışmalar incelendiğinde SGMM'yi doğrudan kullanan çalışmalara rastlanılmadığı, SGMM'nin uyarlanarak veya başka modellerle sentezlenerek kullanıldığı görülmüştür. Bu çalışmada, SGMM'yi uyarlayarak akıllı şebekeye geçiş sürecini planlayan ülke ve bölgeler incelenmekte, modelin yetenek ve karakteristikleri ile SGMM'nin uyarlanmasındaki bazı güçlükler irdelenmektedir. SGMM akıllı şebekelere geçişte yol gösterici olmakla birlikte, yapılan incelemede sadece sertifikalı değerlendiricilerin modeli kullanmak için nitelikli sayılması ve modelin farklı ülkelerin elektrik piyasa yapılarına, sektördeki piyasa oyuncularına göre uyarlanabilir olmaması ve değerlendirmede kullanılan puanlandırma yönteminin açık olmaması başlıca güçlüklerdir. Yapılan çalışmada, Türkiye'nin akıllı şebekelere geçiş için ne aşamada olduğu da incelenmekte, Türkiye açısından modelin kullanımına yönelik güçlü ve zayıf yönler ile kullanımın oluşturacağı firsatlar ve tehditler değerlendirilmekte, öneriler sunulmaktadır.
\end{abstract}

Anahtar Kelimeler-Ak1llı şebeke, olgunluk modeli, akıllı şebeke modelleri, akıllı şebeke yönetimi, olgunluk değerlendirme

\section{Worldwide Adaptations of Smart Grid Maturity Model and Suggestions for Turkey}

\begin{abstract}
With the growing demand for electricity and advancement of technology, countries are trending to smart grids that use information and communication technology and that provide an efficient and reliable infrastructure. Many countries need roadmaps and strategies in order to set their goals and manage the process of achieving the targets in transitioning from traditional grid system to smart grid. In this context, domain specific maturity models are used to meet this need, to facilitate the management of processes and to improve processes. Smart Grid Maturity Model (SGMM) was published for the domain of smart grid in 2011. SGMM has been prepared as a guide for determining targets, establishing roadmaps and management of the transition process to smart grids. Some countries refer to this model during their transition to smart grids; however, when the literature studies are examined, it is seen that there are no studies that directly use SGMM - rather, SGMM is used by adapting or synthesizing with other models. In this study, countries and regions planning the smart grid transition process with adaptation of Smart Grid Maturity Model, the characteristics and capabilities of this model, and
\end{abstract}


advantages and disadvantages of the model in adaptations are examined. Although SGMM is a guide for transitioning to smart grid, the main difficulties are the fact that the only certified evaluators are qualified to use the model, the model is not adaptable to the electricity market of different countries and market players in the sector, and the scoring method used in the assessment is not clear. In this study, Turkey's current state in transitioning to smart grids is also examined; strengths and weaknesses together with opportunities and threats for the use of the model in Turkey are evaluated, and suggestions are proposed.

Keywords - Smart grid, maturity model, smart grid models, smart grid management, maturity assessment

\section{GÍRİŞ (INTRODUCTION) ${ }^{1}$}

Elektrik insanoğlunun günlük yaşantısının ayrılmaz bir parçasıdır ve yükselen yaşam standardı elektriğe olan ihtiyacı sürekli artırmaktadır. Artan bu ihtiyaçtan dolayı elektrik şebekeleri sürekli büyümekte ve bu şebekelerin karmaşıklığı artmaktadır [1]. Kaynak açısından çeşitlenen ve devreye girme/çıkma sıklıkları artan elektrik üreticileri ile kesintisiz ve kaliteli elektrik talebi olan tüketicilerin arasında konumlanan iletim-dağıtım şebekelerinde; yeni tesis ve kapasite genişleme yatırımları ile bakım ve iyileştirme çalışmalarına olan ihtiyaç sürekli büyümektedir. Bu durum ise teknolojinin de ilerlemesiyle birlikte, elektrik sisteminde klasik şebekeler yerine, bilgi ve iletişim altyapısını kullanan akıllı şebekelere yönelimi artırmaktadır.

Akıllı şebeke; elektrik enerjisi üretim, dağıtım ve tüketiminde iletişim ve bilgi teknolojilerinin kullanımının artmasıyla oluşan yeni nesil elektrik güç sistemidir. Sürdürülebilir, ekonomik ve güvenli elektrik kaynaklarını verimli bir şekilde sağlamak için tüm kullanıcıların eylemlerini akıllıca entegre edebilir [2]. Akıllı şebekeler sahip olduğu teknolojik altyapı ile uzaktan ölçme, kontrol etme ve otomatik onarma özelliklerine sahip, fiziksel ve siber saldırılara karşı dayanıklı, dağıtık üretim ve depolamayı destekleyen, tüketici odaklı, çevre dostu, güvenilir ve verimli işletme ortamı imkânları sağlamaktadır [3].

Günümüzde ülkeler stratejik planlarında akıllı şebekelere yer vermekte, k1sa/orta/uzun vadeli hedefler belirleyerek akıllı şebekeye geçiş için yol haritaları oluşturmaktadır [4]. Ak1llı Şebeke Olgunluk Modeli (Smart Grid Maturity Model - SGMM), bu alanda kuruluşlara yardımcı olabilecek bir model olarak öne çıkmaktadır [5]. SGMM, ülkelerin akıllı şebekelere geçişte mevcut olgunluklarının analiz edilmesinde ve hedeflenen olgunluğa ulaşmaları için iş adımlarının oluşturulmasında referans alınmaktadır. SGMM'nin literatürdeki

\footnotetext{
1 A Review on Applications of Smart Grid Maturity Model", The 1st International Eurasian Conference on Science, Engineering and Technology (EurasianSciEnTech 2018), 22-23 Nov 2018, Ankara.
}

uygulamaları incelendiğinde, modelin doğrudan kullanımının yer aldığı bir çalışmaya rastlanmamıştır. Ancak, SGMM'yi uyarlayarak kullanan çalışmalar yer almakta ve bu çalışmalarda SGMM'nin kullanım zorluklarına değinilmektedir. Çalışmalarda belirtilen bu zorluklar modelin kullanımını sınırlamaktadır.

Bu çalışmada, akıllı şebekeye geçişte SGMM'nin yapısı, özellikleri, güçlü ve zayıf noktaları, modelin dünya çapındaki uyarlamaları, Türkiye'de uygulanması imkânı ve zorlukları değerlendirilmiştir. İkinci bölümde, SGMM'nin amacı ve yapısı, akıllı şebeke ile ilgili bilgi alanları ve olgunluk seviyeleri tanıtılmıştır. Üçüncü bölümde, SGMM'yi referans alan ülke ve bölgelerin literatüre giren SGMM uyarlamaları incelenmiş ve SGMM'nin uyarlamalarına ilişkin genel karakteristikler özetlenerek modelin kullanımına yönelik değerlendirmeler yapılmıştır. Dördüncü bölümde Türkiye'deki akıllı şebeke çalışmalarının durumuna değinilmiş, SGMM'nin kullanımının oluşturacağı firsat ve tehditler analiz edilmiş ve Türkiye için önerilerde bulunulmuştur. Beşinci bölümde ise, tüm bu değerlendirmelerden çıkarılan sonuçlar sunulmuştur.

\section{AKILLI ŞEBEKE OLGUNLUK MODELİ (SMART GRID MATURITY MODEL)}

Carnegie Mellon Üniversitesi'nin Yazılım Mühendisliği Enstitüsü (Software Engineering Institute - SEI) tarafindan 2011 yılında yayınlanan SGMM; akıllı şebekelere geçişte hedeflerin belirlenmesi, mevcut süreçlerin değerlendirilmesi, hedeflere yönelik yol haritalarının oluşturulması ve yönetim amaçlarının uygulanmasında yardımcı bir model olarak geliştirilmiştir [5]. SGMM kurumlara; akıllı şebeke yol haritasını oluşturmak/geliştirmek, akıllı şebekeye geçişte hangi aşamada olduklarını belirlemek, ortak bir dil kullanarak iletişim kurmak, süreçleri planlamak ve ölçmek, değişime hazırlamak ve değişimi kolaylaştırmak için yardım eden bir modeldir [6]. Şekil 1'de SGMM'nin model tanımı ve değerlendirme yapısı, Birleşik Modelleme Dili (Unified Modeling Language - UML) ve sınıf diyagramı (class diagram) kullanarak gösterilmiştir. 
SGMM, akıllı şebeke yeteneklerini sekiz alanda (domain) gruplamaktadır [5]. Her bir alan, akıllı şebeke ile ilgili özelliklerin mantıksal bir grubu olarak tanımlanmıştır. SGMM'de akıllı şebeke yetenekleri için tanımlanan alanlar aşağıda belirtilmiştir:

- Teknoloji (bilgi teknolojileri yapısı, standartlar, altyap1 vb.)

- Müşteri (fiyatlandırma, müşteri katılımı ve tecrübe vb.)

- Strateji-yönetim ve düzenleme (vizyon, planlama, paydaş işbirliği vb.)

- Organizasyon ve yapısı (kültür, eğitim, bilgi yönetimi vb.)
- Değer zinciri entegrasyonu (arz ve talep yönetimi, piyasa firsatları vb.)

- Şebeke operasyonları (verimlilik, güvenlik, kontrol vb.)

- $\quad$ İş ve değer yönetimi (değer izleme, bakım vb.)

- Sosyal ve çevresel alanlar (sorumluluk, sürdürülebilirlik vb.)

Modelde yukarıda belirtilen sekiz adet alanının her biri için olgunluk seviyeleri tanımlanmakta ve Tablo 1'de bu olgunluk seviyeleri yer almaktadır. Her bir olgunluk seviyesini başarıyla tamamlamak için alanla ilgili yapılması zorunlu olan ve olmayan özellikler yer almaktadır. Bir kuruluşun belirli bir alanda ve belirli bir

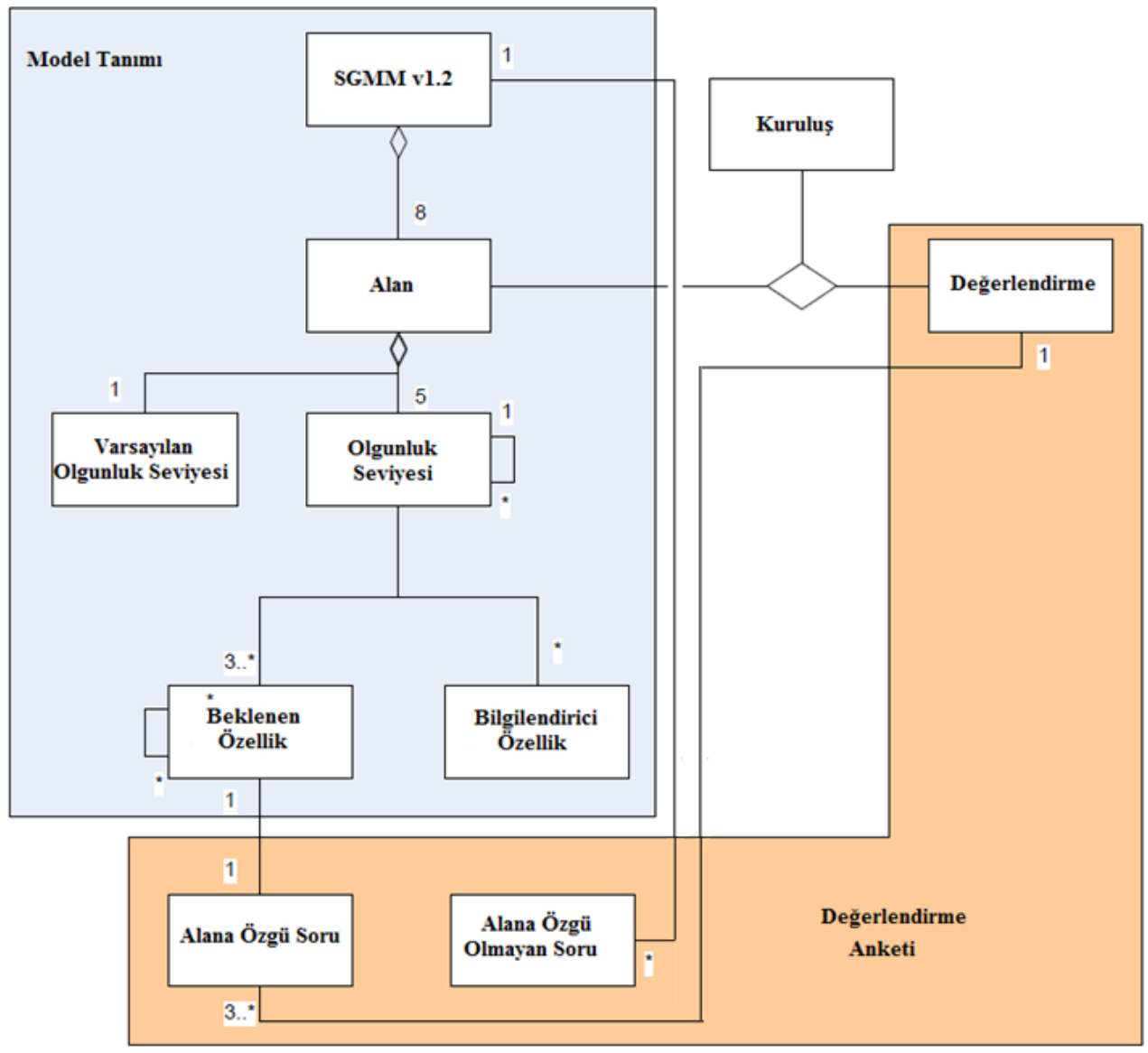

Şekil 1. Akı1lı Şebeke Olgunluk Modeli (SGMM)'nin yapısı

(Architecture of Smart Grid Maturity Model) [5]

olgunluk seviyesinde yerine getirilmesi zorunlu olan özellikleri, beklenen özellikler (expected characteristics) olarak tanımlanmaktadır. Yerine getirilmesi zorunlu olmayan özellikleri ise bilgilendirici özellikler (informative characteristics) olarak tanımlanmaktadır. Modelde beklenen özelliklerin yapılma durumunu değerlendirmek için her bir özelliğe karşılık gelen değerlendirme soruları yer almaktadır. $\mathrm{Bu}$ sorulara verilen cevaplar üzerinden olgunluk değerlendirmesi yapılmaktadır. Ayrıca, kuruluş hakkında bilgi edinilmesini sağlayan ve değerlendirmeye etkisi olmayan sorular da yer almaktadır. 
Şekil 2'de SGMM'deki sekiz alan için örnek bir olgunluk değerlendirme profili gösterilmiştir. Bu profil üzerinden her bir alanın olgunluk seviyesi takip edilebilmektedir. Tablo 2'de ise SGMM'nin yapısını örneklemek amaciyla "Teknoloji” alanının kesiti yer almaktadır. Bu alan, yeni akıllı şebeke teknolojilerinin değerlendirilmesi, toplanmas1, entegrasyonu ve test edilmesi ile ilgili mühendislik ve iş süreçlerinin oluşturulmasını sağlar. Tabloda ikinci olgunluk seviyesi ele alınmış, bu seviyede yer alan dört adet bilgilendirici özellik ve yedi adet yapılması beklenen özellikten ikişer tanesi örnek olarak verilmiş ve bunları değerlendirmek için kullanılan sorular gösterilmiştir.

Elektrik üretimi/dağıtımı/ticareti yapan firmalar/ kuruluşlar (electric utility) SGMM'yi kullanarak akıllı şebeke ile ilgili mevcut olgunluklarını ölçebilmekte ve hedeflerine ulaşabilmek için iyileștirmesi gereken özellikleri tespit edebilmektedir. Ne var ki değerlendirme işlemi sadece sertifikalı (yetkili) değerlendiriciler (SGMM Navigators) tarafından gerçekleştirilmektedir.

\section{AKILLI SEBBEK OLGUNLUK MODELININ DÜNYADAKİ UYARLAMALARI (WORLDWIDE ADAPTATIONS OF SMART GRID MATURITY MODEL)}

Akıllı şebekelere geçişte ülkelerin yol haritası oluşturmasinda, mevcut durumun analizinde ve hedeflerin belirlenmesinde, SGMM referans olarak kullanılmaktadır. Yapılan literatür araştırması sonucunda SGMM'yi doğrudan kullanan çalışmaya rastlanmamıştır. Bununla birlikte, SGMM'yi uyarlayarak akıllı şebekeye geçiş sürecini planlayan altı adet çalışma tespit edilmiştir. Akıllı şebekeler güncel bir konu olmasına rağmen bu alandaki SGMM uyarlamalarının sayıca az olduğu gözlenmiştir. $\mathrm{Bu}$ bölümde, SGMM'yi uyarlayarak kullanan ülke ve bölgeler ana hatlarıyla incelenmiş, uyarlamanın sağladığı faydalar ve getirdiği zorluklar özetlenmiştir.

Tablo1. SGMM olgunluk seviyeleri

(Maturity levels of SGMM) [5]

\begin{tabular}{|c|c|l|}
\hline $\begin{array}{c}\text { Olgunluk } \\
\text { Seviyesi }\end{array}$ & Seviye Adı & Açıklama \\
\hline 5 & $\begin{array}{c}\text { Öncü } \\
\text { (Pioneering) }\end{array}$ & Kuruluş alanla ilgi çı̆̆ır açar ve uygulama pratiklerini ilerletir. \\
\hline 4 & $\begin{array}{c}\text { Optimize } \\
\text { (Optimizing) }\end{array}$ & $\begin{array}{c}\text { Alanla ilgili akıllı şebeke yerleştirmesi kuruluşa göre ayarlanır ve kurumsal } \\
\text { performansı daha da artırmak için kullanılır. }\end{array}$ \\
\hline 3 & $\begin{array}{c}\text { Entegre } \\
\text { (Integrating })\end{array}$ & Alanla ilgili akıllı şebeke uygulaması kuruluşa entegre edilir. \\
\hline 2 & $\begin{array}{c}\text { Etkinleştirici } \\
\text { (Enabling) }\end{array}$ & $\begin{array}{l}\text { Kuruluş, alanla ilgili şebeke modernizasyonunu sağlamayı ve sürdürmeyi } \\
\text { sağlayacak özellikleri uygular. }\end{array}$ \\
\hline 1 & $\begin{array}{c}\text { Başlangıç } \\
\text { (Initiating) }\end{array}$ & Kuruluş, alanla ilgili ilk uygulama adımlarını yapar. \\
\hline 0 & $\begin{array}{c}\text { Varsayılan } \\
(\text { Default })\end{array}$ & Modelin varsayılan seviyesi \\
\hline
\end{tabular}

Tablo 2. SGMM'nin “Teknoloji” alan kesiti

("Technology" domain section of SGMM) [5]

\begin{tabular}{|l|l|}
\hline Alan & Teknoloji \\
\hline Olgunluk Seviyesi & Etkinleştirici (Seviye 2) \\
\hline Beklenen Özellikler & $\begin{array}{l}\text { 2.1. Kuruluş, iş alanlarında taktiksel bilgi teknolojileri (BT) yatırımlarını kurumsal } \\
\text { BT mimarisine (akıllı şebeke hizmetleri sağlamak için) uyumlu hale getirir. } \\
\text { 2.2. Akıllı şebekeyi etkinleştiren kurumsal BT mimarisindeki değişiklikler uygulanır. }\end{array}$ \\
\hline Bilgilendirici Özellikler & $\begin{array}{l}\text { Akıllı şebeke desteğini içeren bir mimari uygulama planı başlatılır. } \\
\text { Kuruluş açık standartların endüstriye uyarlanmasını teşvik eder. }\end{array}$ \\
\hline Alana Özgü Sorular & $\begin{array}{l}\text { 2.1. Taktiksel BT yatırımlarını kurumsal BT mimarisine uyumlu hale getirdiniz mi? } \\
\text { 2.2. Akıllı şebekeyi etkinleştirmek için kurumsal BT mimarinizdeki değişiklikler } \\
\text { uygulandı mı? }\end{array}$ \\
\hline
\end{tabular}




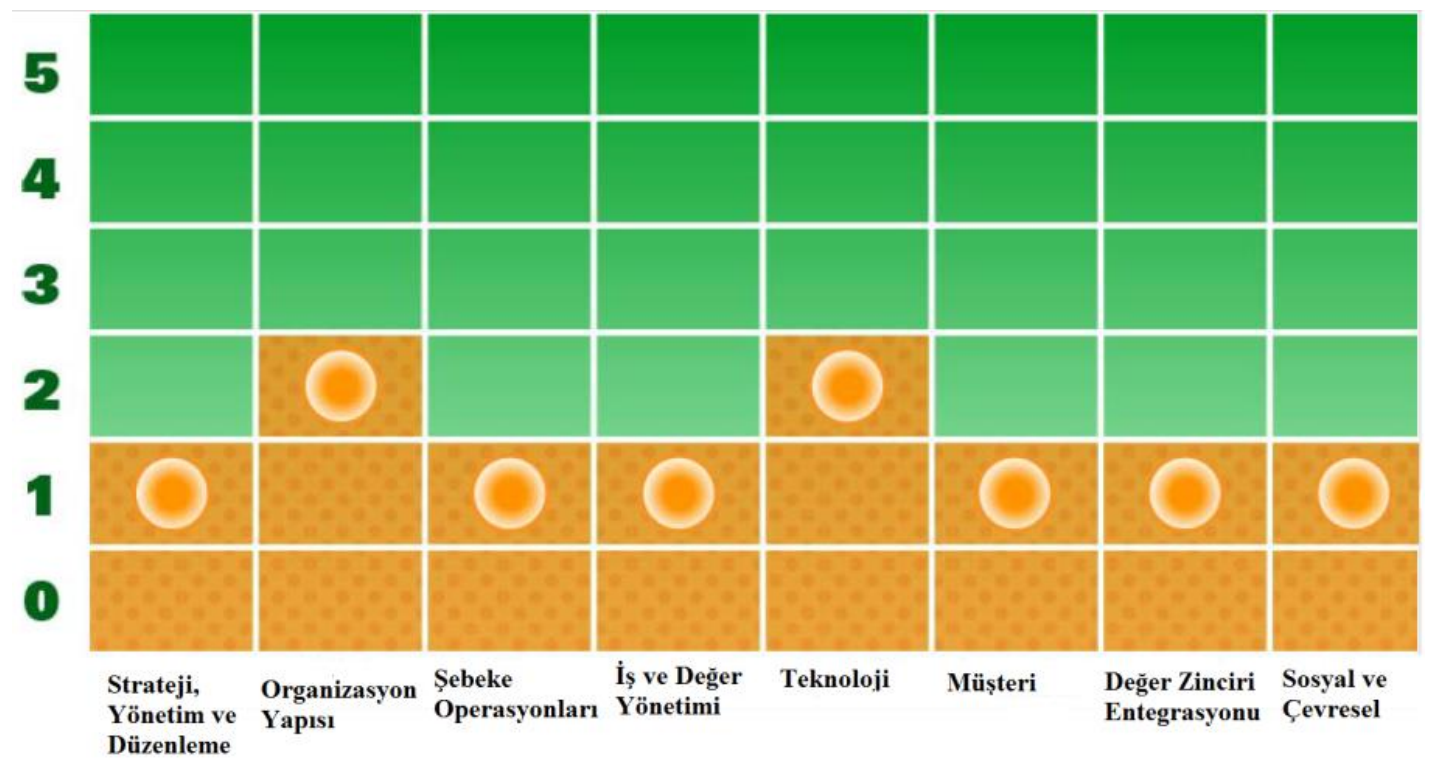

Şekil 2. SGMM olgunluk profili örneği

(An example of SGMM maturity profile) [5]

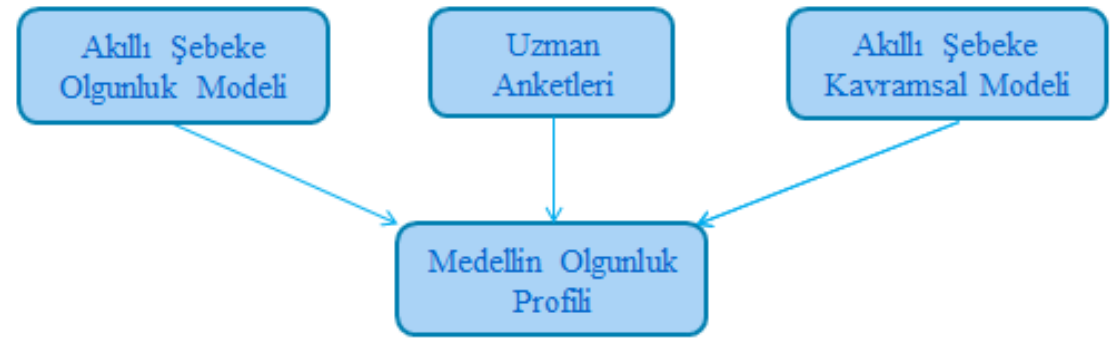

Şekil 3. Medellin şehri için akıllı şebeke olgunluk değerlendirme (Smart grid maturity assessment for Medellin city) [9]

\subsection{Kolombiya (Colombia)}

Kolombiya'da oluşturulan Akıllı Şebeke Yol Haritası'ndaki ilerlemelerin incelenmesi amaciyla SGMM'nin faydalı bir araç olduğu düşünülerek [7] Medellin şehrinin akıllı şebeke teknolojilerine uyarlanmasında mevcut olgunluk seviyesini anlamak için SGMM'den faydalanılmıştır. Bu uygulamada SGMM doğrudan kullanılmamış, Ulusal Teknoloji ve Standartlar Enstitüsü tarafindan istenen ve Elektrik Enerji Araştırma Enstitüsü’nün geliştirdiği [8] Akıllı Şebeke Kavramsal Modeli (Smart Grid Conceptual Model - SGCM) ile sentezlenmiştir [9]. SGCM akıllı şebekeler için yüksek seviye bir çerçeve sunmakta olup bu uygulamada karşılaştırmalı model olarak kullanılmıştır. Ancak, oluşan sentez modelin detayları belirtilmemiştir. Bu iki modelin sentezlenmesi ile şehrin hizmet altyapısı, düzenleyici çerçeve, tüketici bilinci ve iş ortamının olgunluğu değerlendirilmiştir.
Şekil 3'te Medellin şehri için olgunluk değerlendirme yöntemi gösterilmektedir. Değerlendirme çalışmasına üniversiteden araştırmacılar, düzenleyiciler ve politika geliştiriciler, ticari ve endüstriyel tüketiciler ile enerji endüstrisi ve kuruluş çalışanları dâhil olmuştur.

Kolombiya'da yürütülen akıllı şebeke olgunluk değerlendirmesi sonucunda, yapılması gereken düzenlemeler belirlenmiştir.

\subsection{Japonya (Japan)}

Japonya'da, mevcut akıllı şebeke gelişimini değerlendirmek için SGMM'nin kavramsal çerçevesini temel alan sade (refined) bir model tanımlamıştır [10]. SGMM'nin elektrik üretimi/dağıtımı/ticareti yapan işletmeler için bir iş aracı olarak geliştirildiği ve akıllı şebeke teknolojilerine yönelik politikaların kilit unsurlarını tam olarak yansıtmayabileceği düşünülerek 
model doğrudan kullanılmamıştır. SGMM kavramsal çerçevesini kullanarak; hükümet, toplum ve iş odaklı bir yaklaşım sunabilen, hem mevcut durumu değerlendirmek hem de strateji belirlemek için kullanılan sade bir model geliştirilmiştir. SGMM, değerlendirmede kullanılan bu model için çerçeve oluşturmuştur. Değerlendirme çalışması devlet, iş dünyası ve akademiden önemli paydaşların katılımıyla yapılmış ve vaka analizleri ile önemli bulgular elde edilmiştir.

Analiz sonucunda, Japon modeli ile akıllı şebeke gelişiminin ikinci derecesinin elde edildiği, ancak henüz en yüksek seviyeye ulaşılmadığı tespit edilmiştir. En üst olgunluk seviyesine geçilememesinin sebepleri değerlendirme sonucuna göre ortaya koyulmuştur.

\subsection{ABD-Kentucky (USA-Kentucky)}

ABD'nin Kentucky eyaletinde akıllı şebeke yol haritası geliştirilmesi için bir çalışma başlatılmış ve bu yol haritası ile elektrik şebekesinin modernizasyonu hedeflenmiştir. Kentucky'deki akıllı şebeke olgunluğunu belirlemek için SGMM'den faydalanılarak Kentucky Akıllı Şebeke Değerlendirme Modeli (Kentucky Smart Grid Assessment Model - KSGAM) oluşturulmuştur [11]. $\mathrm{Bu}$ modelde SGMM'nin sekiz alanına iki alan daha eklenmiş ve modeldeki alanlar; "Strateji ve Yönetim", "Organizasyon ve Yapısı", "Teknoloji”, "Sistem Mimarisi ve İşletme”, "Arz ve Talep Yönetimi”, "İş ve Değer Yönetimi", "Fiziksel ve Siber Güvenlik", "Hükümet ve Düzenleme”, "Müşteri”, "Çevre ve Sosyal başlıklarıyla yapılandırılmıştır. Her bir grubun olgunluğunu değerlendirmek için SGMM'deki gibi 0-5 seviyesi kullanılmıştır [11]. Bu çalışmada SGMM doğrudan kullanılmamış, modelin değerlendirme alanlarında uyarlamalar ve eklemeler yapılarak eyaletin ihtiyacına uygun bir model oluşturulmuştur.

Kentucky'de yapılan akıllı şebeke olgunluk değerlendirme sonucunda akıllı şebekenin gelişiminde müşteri istekliliği, teknolojik engeller, düzenleme ve politika değişiklikleri, ticari ve finansal zorluklar gibi engeller belirlenmiştir. Hedeflere ulaşmak için kısa, orta ve uzun vadeli yol haritaları oluşturulmuştur.

\subsection{Hindistan (India)}

Hindistan için akıllı şebeke alanlarından biri olan Talep Katılımı'nın (Demand Response-DR) uygulanması, doğru teknoloji ve DR programlarının seçilmesi ve DR düzenleyici çerçevesinin oluşturulması için SGMM'den faydalanılmıştır.

SGMM'deki "Şebeke Operasyonları”, "Müşteri”, "Değer Zinciri Entegrasyonu", "Sosyal ve Çevresel" alanları talep katılımı olgunluğunu belirlemek için referans alınmıştır. $\mathrm{Bu}$ alanlardan yararlanılarak Tablo 3'te gösterilen Talep Katılımı Olgunluk Döngüsü (DR Maturity Cycle) oluşturulmuştur [12]. Aynı şekilde SGMM'deki 5 adet olgunluk seviyesinden yararlanılmış, ancak bu çalışmada, ilk iki olgunluk seviyesi birleştirilerek 4 adet olgunluk seviyesi belirlenmiştir. Böylece, SGMM'nin müşteri ile ilgili talep tarafı yönetimi alanı Hindistan'a göre uyarlanarak ülkeye özgü bir talep katılım döngüsü tanımlanmış ve Hindistan'daki talep katılım olgunluğunun değerlendirilmesine katk1 sağlanmıştır.

Tablo 3. Hindistan talep katılımı olgunluk döngüsü (Demand response maturity cycle of India) [12]

\begin{tabular}{|c|l|}
\hline Seviyeler & Olgunluk Döngüsü Adımları \\
\hline 1. Aşama & $\begin{array}{l}\text { Başla: Manuel küçük ölçekli talep katılım } \\
\text { programları }\end{array}$ \\
\hline 2. Aşama & $\begin{array}{l}\text { Ölç ve öğren: Çoklu teknolojiler, gelişmiş ana } \\
\text { hizmet sağlayıcılar }\end{array}$ \\
\hline 3. Aşama & $\begin{array}{l}\text { Zorlukları ortaya çıkar: Birçok bileşen, iletişim } \\
\text { kanalı ve açı standartlar }\end{array}$ \\
\hline 4. Aşama & $\begin{array}{l}\text { Bir talep katılım yönetim sistemi (DRMS) } \\
\text { oluşturmak, teknoloji karmaşılıklarını } \\
\text { soyutlamak, bütünleştirmek ve } \\
\text { otomatikleştirmek }\end{array}$ \\
\hline
\end{tabular}

Geliştirilen DR Olgunluk Döngüsü'nün birinci aşamasında tüketicilerin talep katılımı yapmaları için bildirimler telefon, e-posta veya k1sa mesaj yoluyla gelmekte, tüketim azaltma veya kaydırma işlemi manuel yapılmaktadır. Ölçme ve doğrulama işlemi ise talep katılımının sağlandığı zamandaki tüketim ile geçmişteki benzer gün ve zaman dilimindeki tüketim karşılaştırılarak yapılmaktadır. İkinci aşamada; yük kontrol cihazları, iletişim cihazları ve çoklu cihaz iletişim yolları kullanılmakta ve birçok talep katılım programları uygulanmaktadır. Tüketicinin programa ne kadar katılım sağladığını ölçmek için, belirli bir saatte talimat almadığı varsayımı altında tüketeceği öngörülen enerji miktarı olan temel tüketim yaklaşımı esas alınmaktadır. Ayrıca, talep toplayıcılar piyasaya katılmakta ve küçük tüketicilerin de piyasaya katılımını sağlayan havuzlar oluşturulmaktadır. Modelin üçüncü aşamasında; sistemin büyümesinden dolayı cihaz çeşitliliği artmakta, farklı yük yönetim yöntemleri geliştirilmekte ve cihazların birbiriyle iletişiminde zorluklar yaşanmaktadır. Standardizasyon eksikliği darboğazlara neden olmakta, cihazların ve ölçüm sistemlerinin, talep yönetim sistemine kolaylıkla adaptasyonunu sinırlamaktadır. Dolayısıyla talep katılım portföyü yönetilemez bir duruma gelmektedir. $\mathrm{Bu}$ durumda merkezi ve otomatik bir talep yönetim sistemine ihtiyaç duyulmaktadır. Dördüncü aşamada ise talep katılım yönetim sistemi kullanılmakta, cihazlar sisteme kolaylıkla entegre 
edilebilmekte, ölçme ve doğrulama işlemi otomatik yapılmakta, talep katılım miktarları ve kazançları hesaplanabilmekte ve müşterilere gerçek performansları oranında ödeme yapılabilmektedir.

\subsection{Avrupa (Europe)}

Bazı uzmanlara göre SGMM, Amerika Birleşik Devletleri'nin enerji sektörü yapısına uygun iken Avrupa için uygulanabilir bir model değildir [13]. Avrupa'nın elektrik piyasası yapısı ABD'nin elektrik piyasasına göre farklıdır. Yine aynı uzmanlara göre model, sektördeki tüm paydaşlar için ortak bir yaklaşım (one-size-fits-all approach) sunmasından dolayı farklı paydaşlar için konfigüre edilememektedir. Ayrıca, herkese açık bir değerlendirme mekanizması yoktur. Bu kritiklerden dolayı SGMM, Avrupa'daki akıllı şebeke olgunluğunun değerlendirilmesi için uygulanabilir bulunmadığından model üzerinde değişiklikler yapılmıştır. SGMM, Avrupa'nın ihtiyaçlarına göre adapte edilerek "Uyarlanabilir Akıllı Şebeke Olgunluk Modeli (Adaptive SGMM)" geliştirilmiştir [13]. Modelin uyarlanmış versiyonu ile farklı etkinlikler ve gelişim yaklaşımları arasında kıyaslama imkânı sağlanmıştır. Ayrıca, akıllı şebeke yaklaşımlarını uluslararası düzlemde kıyaslama imkânı da sağlanmıștır.

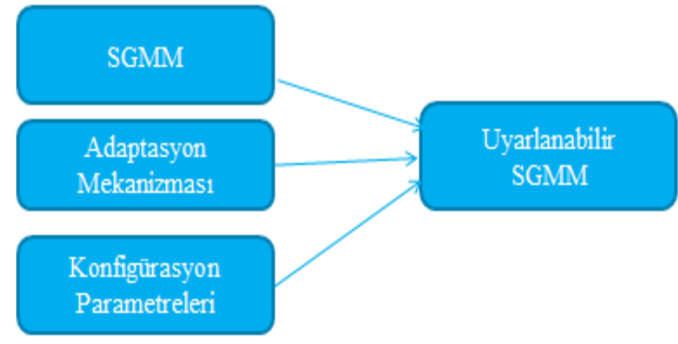

Şekil 4. Uyarlanabilir Akıllı Şebeke Olgunluk Modeli yap1s1

(The structure of Adaptive Smart Grid Maturity Model) [13]

Uyarlanabilir Akıllı Şebeke Olgunluk Modeli (ASGMM) Şekil 4'te gösterildiği gibi, SGMM temel alınarak modele farklı bağlamlara uyarlanmasını sağlayan adaptasyon mekanizmaları ve modelin özel durumlar (örneğin, farklı rollere sahip kuruluşlar) için kullanılabilmesini sağlayan konfigürasyon parametreleri eklenerek oluşturulmuştur. Konfigürasyon için parametreler ve değerleri tanımlanmıştır. Bu parametreler Tablo 4'te verilmiştir. Örneğin "Market Yapısı", ayrıştırılmış piyasa, bölgesel piyasa vb. farklı piyasa yapılarının seçilmesini; "Organizasyon Tipi”, dağıtım şirketi ve iletim şirketi gibi farklı rollere sahip kurumlara göre uyarlamayı; "Akıllı Şebeke Bakış Açııı" ise ekonomiklik, sürdürülebilirlik ya da güvenilirlik değerlerinden ağırlık verilecek özelliklerin seçimini desteklemektedir. Şekil 5'te SGMM'den ASGMM oluşturma ve kullanma süreci gösterilmiştir.

Tablo 4. ASGMM konfigürasyon parametreleri (Configuration parameters of ASGMM) [13]

\begin{tabular}{|l|l|}
\hline \multicolumn{2}{|c|}{ Parametreler } \\
\hline Değer Zinciri & Odak Konusu \\
\hline Market Yapısı & $\begin{array}{l}\text { Bilgi ve İletişim } \\
\text { Teknolojileri Boyutu }\end{array}$ \\
\hline Organizasyon Tipi & Kesişen Konular \\
\hline $\begin{array}{l}\text { Akıllı Şebeke Boyutu/ } \\
\text { Bakış Açısı }\end{array}$ & Boyutu \\
\hline
\end{tabular}

Geliştirilen bu modelin örnek konfigürasyonu Almanya'da yol haritasının oluşturulmasında kullanılmıştır. Yapılan durum çalışmasında SGMM'deki "Teknoloji" alanı için bu uyarlama işlemi yapılmış olup diğer yedi alan için de uyarlanabilirliğin doğrulanacağ 1 belirtilmiştir. Ayrıca, gelecek çalışmalarda modelin farklı kuruluşlar, projeler vb. için kullanımının değerlendirileceği belirtilmiştir.

Uyarlanabilir SGMM (ASGMM), hem Amerika Birleşik Devletleri hem de Avrupa piyasası için kullanılabilir bir

model olmuştur. SGMM'de metrikler önceden tanımlı ve tüm alanlar için uygulanmakta iken ASGMM'de, özel metrikler eklenebilmektedir. SGMM sektördeki rollerden (dağıtım şirketi, iletim şirketi, üretim şirketi vb.) bağımsız geliştirilmiştir; ASGMM ise rollere göre uyarlanabilmektedir. $\mathrm{Bu}$ değerlendirmenin sonucu SGMM'nin yapısının esnek olmadığını göstermektedir.

\subsection{Umman (Oman)}

Umman'da akıllı şebekelerin faydalarını tahmin etmek ve buna bağlı olarak strateji belirlemek için SGMM'den faydalanılmıştır [14]. Talep tarafı yönetimi, enerji verimliliği ve dağıtık üretimin faydalarını değerlendirmek amaciyla SGMM'de yer alan sekiz adet alan için senaryolar üretilmiş ve bu senaryoların üretim, iletim, dağıtım ve çevresel maliyetlerinden kaçınma maliyetleri hesaplanarak faydaları ve yük düşümüne katkısı analiz edilmiştir. Bu uygulamada SGMM, akıllı şebeke stratejilerini oluşturmak için senaryo üretme amacıyla kullanılmıştır.

Senaryolar şebekenin iyileştirilmesini, müşterilerin şebekeye katkısını ve her ikisinin birlikte kullanımını içermektedir. Bu kapsamda üretilen senaryolar Tablo 5'te gösterilmiştir. Üretilen senaryolar için olgunluk 
seviyeleri ve yapılması gereken pratikler tanımlanmıştır. Şekil 6'da senaryoların olgunluk seviyelerine göre eşleştirilmesi yer almaktadır.

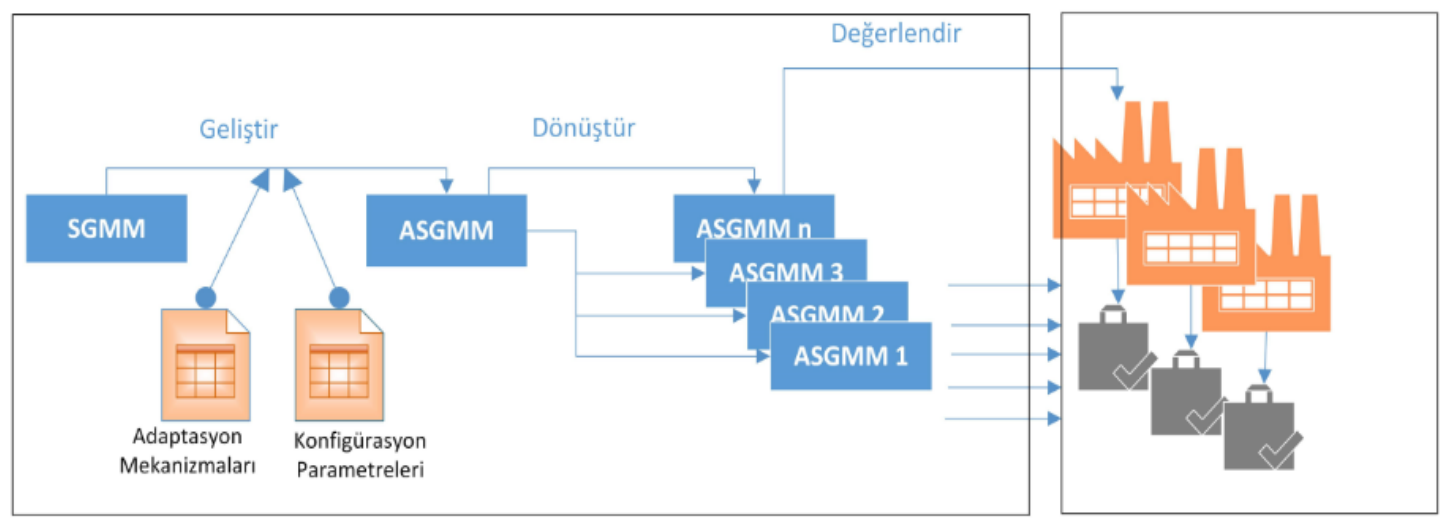

Şekil 5: ASGMM oluşturma ve kullanma süreci

(The process of creating and using ASGMM) [13]

Tablo 5. Üretilen senaryolar (Produced scenarios) [14]

\begin{tabular}{|l|l|l|l|}
\hline Senaryo & Durum & Olgunluk Seviyesi & Açıklama \\
\hline Senaryo 1 & Temel durum & $\begin{array}{l}\text { Tüm alanların olgunluk seviyesi } \\
\text { 0 (sıfır)'dır. }\end{array}$ & $\begin{array}{l}\text { Kuruluşlar, akıllı şebeke entegrasyonu veya talep } \\
\text { tarafı yönetimini düşünmemektedir. }\end{array}$ \\
\hline Senaryo 2 & Minimum akıllı & $\begin{array}{l}\text { Tüm alanların olgunluk seviyesi } \\
1 \text { ile 2 arasında iken çalışma } \\
\text { sonunda 2 ile 3 arasında çıkar. }\end{array}$ & $\begin{array}{l}\text { Enerji verimliliği ve tasarrufu için metrikler } \\
\text { tanımlanır. }\end{array}$ \\
\hline Senaryo 3 & $\begin{array}{l}\text { Tavsiye edilen talep } \\
\text { tarafı yönetimi }\end{array}$ & $\begin{array}{l}\text { "Müşteri” alanın olgunluk } \\
\text { seviyesi 2 iken diğer 7 adet } \\
\text { alanın olgunluk seviyesi 1'dir. }\end{array}$ & $\begin{array}{l}\text { Hane halkı tüketicilerinde kuruluşların veya } \\
\text { müşterilerin yatırım yapmasına gerek kalmadan } \\
\text { enerjinin verimli kullanımı için pratikler, diğer bir } \\
\text { deyişle talep tarafi yönetimi kullanılır. }\end{array}$ \\
\hline Senaryo 4 & Dağıtık üretim & $\begin{array}{l}\text { Tüm alanların olgunluk seviyesi } \\
\text { 3 ile 4 arasındadır. }\end{array}$ & $\begin{array}{l}\text { Hane halkı tüketicilerinin güneş panelleri kurarak } \\
\text { puant taleplerini azalttıkları farz edilir. }\end{array}$ \\
\hline Senaryo 5 & Hibrit (PV\&DSM) & $\begin{array}{l}\text { Tüm alanların olgunluk seviyesi } \\
\text { 3 ile 4 arasındadır. }\end{array}$ & $\begin{array}{l}\text { Dağıtık üretim ve talep tarafı yönetiminin birlikte } \\
\text { kullanıldığ farz edilir. }\end{array}$ \\
\hline
\end{tabular}

Senaryolarda yapılması gereken işler belirlenerek durum çalışmaları gerçekleştirilmiş ve senaryoların maliyetleri analiz edilerek fayda-maliyet oranları çıkarılmıştır. Talep katılımının uygulanmasıyla büyük oranda tasarruflar elde edileceği ve uygulamanın çok fazla bir yatırım gerektirmeyeceği sonuçlarına varılmıştır. Yapılan analiz sonucunda, en yüksek fayda-maliyet oranına sahip senaryonun talep katılımının uygulandığı Senaryo 3 olduğu tespit edilmiştir. Senaryo çalışmaları Umman'ın akıllı şebekeler için gelecek stratejilerini ve iş planlarını belirlemesinde çerçeve oluşturmuştur.

\subsection{Akıllı Şebeke Olgunluk Modeli Uyarlamalarının Değerlendirilmesi (Evaluation of Smart Grid Maturity Model Adaptations)}

Akıllı Şebeke Olgunluk Modeli'nin kılavuz olarak kullanıldığı çalışmalar incelendiğinde modelin şehir, ülke ya da bölge gibi farklı büyüklükteki bağlamlarda uyarlamaları görülmektedir. Bunun yanı sıra, model genel değerlendirme amaçlı kullanılabilir ya da modelin alt alanlarından biri veya birkaçı temel alınarak değerlendirmeler yapılabilir. Ayrıca, incelenen çalışmaların tamamında kullanıldığı şehir, ülke veya 
bölgeye göre modelde uyarlama yapılmakta ve çalışmalardan biri (Hindistan örneği [12]) hariç hepsinde, pilot çalışma/vaka analizi yapılarak uyarlanan model test edilmektedir. SGMM'nin kullanımıyla ilgili örneklere ilişkin genel değerlendirme Tablo 6'da; "Uygulama Referansı", "Uygulama Kapsamı (Coğrafi)", "SGMM
Kapsamı", "Uyarlama Yapılmış Mı?”, "Pilot Çalışma/Durum Çalışması Yapılmış Mı?”, "Değerlendirmeye Katılanlar", "Raporlanan Başarı Unsurları" ve "Raporlanan Zorluklar" başlıklarına göre verilmiştir.

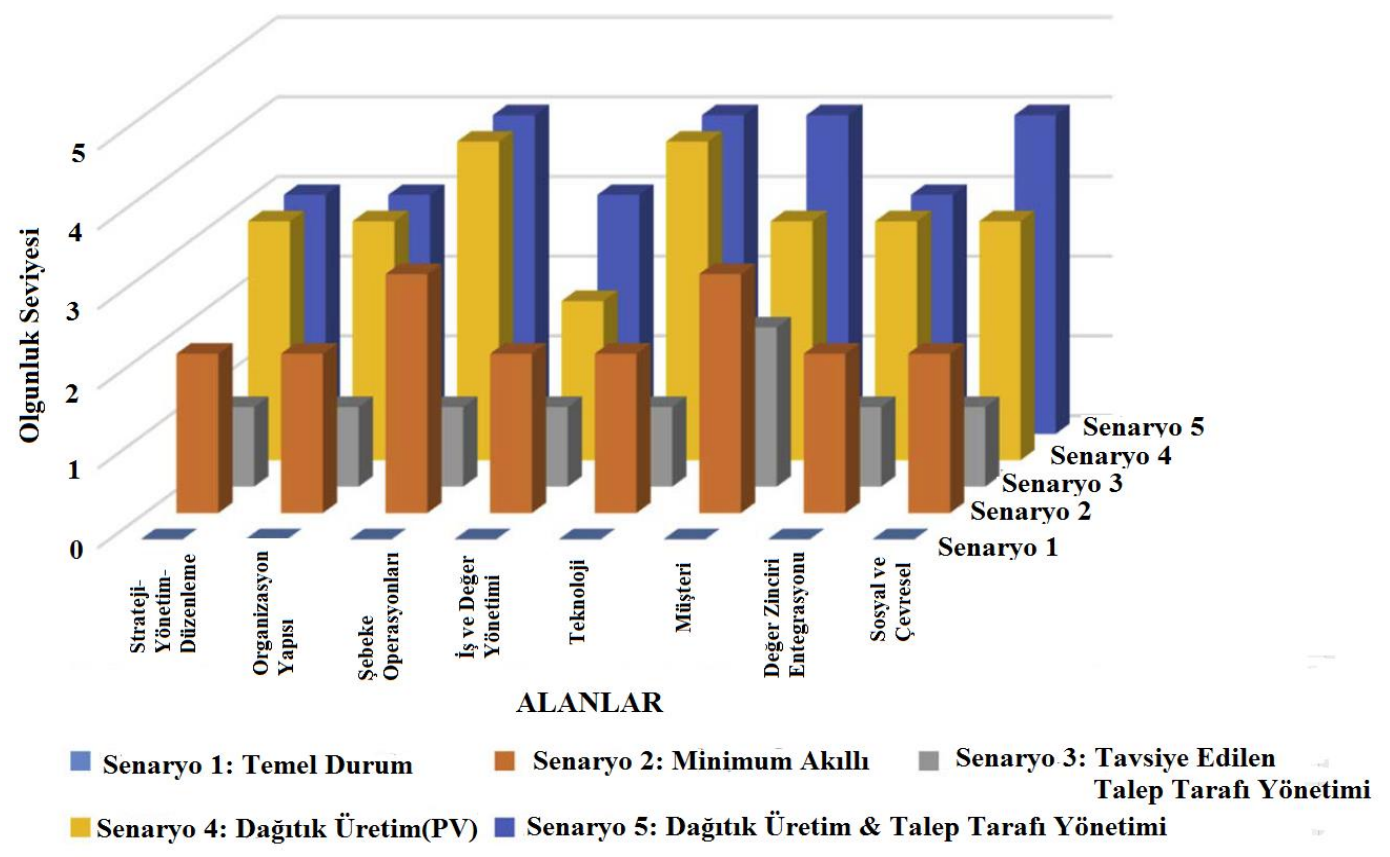

Şekil 6. Akıllı şebeke olgunluk seviyeleri açısından üretilen senaryolar (Scenarios in term of smart grid maturity levels) [14]

SGMM'nin uyarlanarak kullanımıyla ilgili örnekler incelendiğinde, modelin ülke ve bölgelere fayda sağladığ 1 görülmektedir. Bunun yanı sıra modelin kullanımı sırasında bazı zorluklar da ortaya çıkmaktadır.

Literatürdeki bu örneklerden yola çıkarak SGMM'nin sağladığı faydalar şöyle özetlenebilir:

- Akıllı şebekelere geçişte akıllı şebeke yetenekleri için belirlenen gruplar/alanlar bazında mevcut durumun olgunluğunu gösterir.

- Hedeflerin bu gruplar/alanlar bazında belirlenmesini sağlar ve hedeflenen olgunluk seviyelerine göre hedeflerin önem derecelerini gösterir.

- Mevcut durum ve hedeflere bakılarak atılması gereken adımları belirler.

- Hedeflere ulaşmanın önündeki eksikler ve engelleri tespit eder. Bu eksikler ve engellerden yola çıkarak yapılması gereken düzenlemeleri ortaya koyar.

- Modelde yer alan değerlendirme soruları ile akıllı şebekelere geçişteki değişim sürecini yönetir.

- Ülkelerin kendilerine uygun geliştirdikleri modellere temel olur.
SGMM'nin uyarlanarak uygulanması sirasında ortaya çıkan zorluklar ise şöyle özetlenebilir:

- Farklı ülkelerin elektrik piyasa yapıları için doğrudan kullanılamamaktadır. Ülkeler kendi şartlarına göre modeli uyarlamak veya sadeleştirmek durumunda kalmıştır.

- Modelde yer alan değerlendirme sorularının puanlandırma şekli ve kriterleri herkese açık değildir.

- Model, elektrik piyasası sektöründeki farklı rollere sahip kuruluşlar için özel pratikler yerine, tüm paydaşlar için ortak bir yaklaşım sunmaktadır.

- Olgunluk seviyelerine bakıldığında alt seviyedeki tüm özellikler yerine getirilmeden, bir üst seviyedeki özelliklerin çoğunluğu yerine getirilebilmektedir.

- Bir alanda olgunluk seviyelerinde belirtilen karakteristikler kimi zaman birbirinden bağımsız olup alanın farklı boyutlarını ele almaktadır. Örneğin; "Teknoloji” alanında hem BT altyapısı hem de araç (tools) karakteristikleri yer almaktadır. Bu iki karakteristik birbirinden bağımsız ve kıyaslanabilir 
olmadığı için tüm olgunluk basamaklarında ayrı ayrı ele alınmalıdır.

SGMM, akıllı şebekelere geçişte ve olgunluk değerlendirmede referans bir model olmakla birlikte yukarıda bahsedilen uyarlama zorlukları modelin yapısından kaynaklanmaktadır. Bu zorluklar, bu alanda geliştirilecek olgunluk modelleri için dikkate alınması gereken hususlardır. Ayrıca, Tablo 6'da özetlenen raporlanmış başarı unsurları ve zorlukları, olgunluk değerlendirme sırasında yapılması ve yapılmaması gerekenlerin tespitine yardımcı olmaktadır.

Yapılan örnek çalışmalardan yola çıkarak olgunluk değerlendirme başarısını artırmak için yapılması gerekenler şöyle özetlenebilir:

- Farklı yaklaşımlar sunabilecek akademi, özel sektör, düzenleyici kurum vb. farklı yerlerde çalışan kişilerle çalışma ve değerlendirme yapılmalıdır.

- Değerlendirmede kullanılacak bilgilerin doğruluk ve gerçekliğini artırmak için tek bir yöntem yerine ikili görüşmeler, anket, çalıştay gibi farklı yöntemler kullanılmalıdır.

- Kullanılan olgunluk değerlendirme modeli ülkenin elektrik piyasa yapısına, kuruluşun organizasyon tipine, bakış açısına vb. uyarlanabilir olmalıdır.

- Modelde değerlendirme için kullanılan sorular puanlama yöntemiyle birlikte verilmelidir.

- Değerlendirmeler pilot çalışmalarla veya durum çalışmalarıyla desteklenmelidir.

- Model, farklı aktiviteler ve geliştirme yaklaşımları arasında kolay karşılaştırma sunmalıdır.

Olgunluk değerlendirme başarısını artırmak için yapılmaması gerekenler ise şöyle özetlenebilir:

- Endüstri akıllı şebeke gelişiminde öncü iken, akademi ve düzenleyici kurumlar geride kalmamalıdır.

- Teşvikler ve mevzuat pilot çalışmaların gerisinde kalmamalıdır

- Tüketicilerin piyasaya katılımı için tüketici farkındalık eksikliği ve alana yönelik eğitim eksikliği olmamalıdır. Tüketicinin piyasaya katılımında engeller olmamalıdır.

- Olgunluk modeli farklı elektrik piyasaları veya farklı kuruluşlar için uyarlanamaz olmamalıdır.

- Modelde yer alan bir olgunluk seviyesindeki tüm karakteristikler yerine getirilmeden bir üst seviyeye geçilmemelidir.
- Uygulamaların daha geniş kapsamda yayılımı için, yapılan pilot çalışmalarla yetinilmemelidir.

\section{TÜRKIYE'DE AKILLI ŞEBEKE CCALIŞMALARI İÇIN DEĞERLENDIRME VE ÖNERILER (EVALUATION AND SUGGESTIONS ON SMART GRID STUDIES IN TURKEY)}

Türkiye'de dağıtım bölgelerinin özelleştirilmesiyle birlikte şirketler kayıp-kaçak oranını azaltmak ve şebekede iyileştirmeler yaparak kazançlarını artırmak için ak1llı şebekelere yönelmiştir. Türkiye'de akıllı şebeke çalışmalarının yapılması için Enerji ve Tabii Kaynaklar Bakanlığı (ETKB) koordinatörlüğünde kamu, özel sektör ve sivil toplum kuruluşlarının katılımları ile Enerji Verimliliği Strateji Belgesi (2012-2023) hazırlanarak eylemler planlanmıştır [15]. Ayrıca 2018 yılında yayımlanan "Ulusal Enerji Verimliliği Eylem Planı'nda (2017-2023)" akıllı sayaçların yaygınlaştırılması eylemi kapsamında nihai tüketicilerin akıllı ölçüm sistemleriyle donatılması ve talep tarafı katılımı uygulaması için piyasa altyapısının oluşturulması eylemi kapsamında akıllı sayaç ve pilot uygulamaların desteklenerek akıllı şebeke demo alanlarının oluşturulması planlanmıştır [16]. Akıllı şebeke çalışmaları kapsamında Türkiye Elektrik İletim A.Ş. (TEİAŞ) tarafından elektrik piyasası yönetim sistemi için sahadan sayaç verilerinin günlük olarak toplanması, verilerin işlenmesi ve iletim şebekesi uzlaştırmasının yapılması amacıyla Otomatik Sayaç Okuma Sistemi (OSOS) geliştirilmiş ve ulusal elektrik şebekesinin gerçek zamanlı izlenmesi için SCADA ve Enerji Yönetim Sistemi (EMS) kurulmuştur [17]. Ayrıca dağıtım şirketleri de kendi akıllı şebeke çalışmalarını yürütmektedir.

Türkiye'de farklı olgunluk seviyesinde bulunan dağıtım şirketlerinin 2035 yılına kadar aynı olgunluk seviyesinde buluşturulması için, Enerji Piyasası Düzenleme Kurumu (EPDK) koordinatörlüğünde başlatılan Türkiye 2023 Akıllı Şebekeler Yol Haritası (TAŞ23), Elektrik Dağıtım Hizmetleri Derneği (ELDER) tarafindan hazırlanmıştır [18]. Türkiye 2023 Akıllı Şebekeler Yol Haritası; 2023 yılına kadar kısa ve orta, 2035 y1lına kadar uzun dönem olacak şekilde planlanmıştır. TAŞ23'te akıllı şebekelerle ilgili olarak; akıllı şebeke şirket vizyon ve stratejisi, gelişmiş şebeke izleme, kontrol ve yönetim sistemleri, BT altyapıları ve veri analitiği, kurumsal uygulama entegrasyonu, dağıtık üretim entegrasyonu ve depolama, varlık yönetimi ve CBS (Coğrafi Bilgi Sistemi), elektrikli araçlar, akıllı sayaç altyapıları ve müşteriler, haberleşme altyapıları, siber güvenlik gibi teknik bileşenler yer almaktadır [18]. 
Tablo 6. SGMM uyarlamalarının değerlendirilmesi

(Evaluation of SGMM adaptations)

\begin{tabular}{|c|c|c|c|c|c|c|c|}
\hline $\begin{array}{l}\text { Uygulama } \\
\text { Referansı }\end{array}$ & $\begin{array}{l}\text { Uygulama } \\
\text { Kapsamı } \\
\text { (Coğrafi) }\end{array}$ & $\begin{array}{l}\text { SGMM } \\
\text { Kapsamı }\end{array}$ & $\begin{array}{l}\text { Uyarlama } \\
\text { Yapılmış } \\
\text { Mı? }\end{array}$ & $\begin{array}{l}\text { Pilot } \\
\text { Çalış̧ma/ } \\
\text { Vaka } \\
\text { Çalışması } \\
\text { Yapılmış } \\
\text { Mı? }\end{array}$ & $\begin{array}{l}\text { Değerlendirmeye } \\
\text { Katılanlar }\end{array}$ & Raporlanan Başarı Unsurları & Raporlanan Zorluklar \\
\hline $\begin{array}{l}\text { Kolombiya } \\
\text { [9] }\end{array}$ & Şehir & $\begin{array}{l}\text { - Kuruluş } \\
\text { altyapısı } \\
\text { - Mevzuat } \\
\text { - Müşteri } \\
\text { farkındalığı } \\
\text { - İş geliştirme }\end{array}$ & Evet & Evet & $\begin{array}{l}\text { - } \text { Akademisyenler } \\
\text { - Düzenleyiciler ve } \\
\text { politika geliştiriciler } \\
\text { - Ticari ve endüstriyel } \\
\text { tüketiciler } \\
\text { - Enerji endüstrisi ve } \\
\text { kuruluş çalışanları }\end{array}$ & $\begin{array}{l}\text { - Sektördeki uzmanlarla birlikte değerlendirme } \\
\text { yapılması } \\
\text { - Pilot çalışma yapılması } \\
\text { - Değerlendirme sonucuna göre akıllı şebekelerin } \\
\text { uygulanmasıyla ilgili senaryolar üretilmesi } \\
\text { - Akıllı sayaç sisteminin olması } \\
\text { - SCADA sisteminin olması } \\
\text { - Elektrik işletmeleri altyapısının gelişmiş olması } \\
\text { - Yol haritasının oluşturulması }\end{array}$ & $\begin{array}{l}\text { - Tüketici farkındalı̆̆ının eksik olması } \\
\text { - Akıllı şebeke aktörlerinin alana } \\
\text { yönelik ěgitim eksikliğ } \\
\text { - Dağı ürı üretim için düzenleme } \\
\text { olmaması } \\
\text { - Elektrik işletmeleri akıllı şebeke } \\
\text { gelişiminde öncü iken; akademi, } \\
\text { endüstri ve düzenlemelerin geride } \\
\text { kalması }\end{array}$ \\
\hline $\begin{array}{l}\text { Japonya } \\
{[10]}\end{array}$ & Şehir & $\begin{array}{l}\text { - Enerji } \\
\text { yönetim } \\
\text { sistemleri } \\
\text { - Talep } \\
\text { katılımı } \\
\text { - Dağıtık güç } \\
\text { sistemi } \\
\text { - Dinamik } \\
\text { fiyatlan- } \\
\text { dırma } \\
\text { - Elektrikli } \\
\text { araçlar }\end{array}$ & Evet & Evet & $\begin{array}{l}\text { - Şirket yöneticileri } \\
\text { - Akademisyenler } \\
\text { - Politika düzenleyiciler }\end{array}$ & $\begin{array}{l}\text { - Değerlendirmeye hem akademiden hem de } \\
\text { sektörden kişilerin katılımı } \\
\text { - Masa başı araştırmaları, alan gözlemleri ve } \\
\text { paydaşlarla röportajlar yapılarak nitel bir } \\
\text { yaklaşım uygulanması } \\
\text { - Dört farklı şehirde pilot uygulama yapılması } \\
\text { - Uyarlanan modelin SGMM çerçevesi ve kilit } \\
\text { kavramları (devletin vizyon oluşturması, politika } \\
\text { geliştirme, elektrik piyasasını düzenleme) } \\
\text { birleştirmesi } \\
\text { - Uyarlanan modelin hükümet, iş ve toplum odaklı } \\
\text { olmak üzere farklı yaklaşımlar sunması } \\
\text { - Japonya Hükümeti’nin liderlik kapasitesi, } \\
\text { kurumsal kapasite, etkinleştirme kapasitesi ve } \\
\text { teşvik kapasitesine sahip olması }\end{array}$ & $\begin{array}{l}\text { - SGMM'nin elektrik işletmeleri için } \\
\text { geliştirilmiş bir araç olmas, } \\
\text { dolayısıyla politika bağlamındaki kilit } \\
\text { unsurları tam olarak yansıtmaması } \\
\text { - Mevzuatın yetersizliği } \\
\text { - Teşvik sisteminin olmamas } \\
\text { - Tüketicinin piyasaya katılımında } \\
\text { engeller olması } \\
\text { - Pilot projelerin daha büyük ölçekli } \\
\text { yayıllıma geçememesi } \\
\text { - İş modellerinin gelişiminin az olması }\end{array}$ \\
\hline $\begin{array}{l}\text { ABD- } \\
\text { Kentucky } \\
\text { [11] }\end{array}$ & Eyalet & $\begin{array}{l}\text { Genel } \\
\text { değerlendirme }\end{array}$ & Evet & Evet & $\begin{array}{l}\text { - Elektrik işletmeleri } \\
\text { - Elektrik işletmeleri } \\
\text { dişındaki paydaşlar }\end{array}$ & $\begin{array}{l}\text { - Değerlendirme için anket, yüz yüze görüşmeler, } \\
\text { çalıştaylar vb. farklı yöntemler kullanılarak } \\
\text { bilgilerin toplanması } \\
\text { - Değerlendirme için akademi, sektör kuruluşları, } \\
\text { hükümet ve paydaş yetkilileri olmak üzere farklı } \\
\text { rollerden katıllım olması } \\
\text { - SGMM'nin uyarlanarak değerlendirme } \\
\text { alanlarının ihtiyaca göre revize edilmesi } \\
\text { - Hem elektrik işletmeleri hem elektrik işletmeleri } \\
\text { dışındaki paydaşlar ile değerlendirme yapılması } \\
\text { - Elektrik işletmelerinin strateji geliştirme ve } \\
\text { yönetimi, teknoloji ve müşteri alanlarında belirli } \\
\text { bir aşama kaydetmesi } \\
\text { - Elektrik işletmeleri paydaşların verimli işletme }\end{array}$ & $\begin{array}{l}\text { - Teknoloji araştırma ve geliştirme ile } \\
\text { gerçekleştirme ve uygulamalarının } \\
\text { maliyetlerinin yüksek olması } \\
\text { - Yeni teknolojileri araştırma ve } \\
\text { geliştirme eksikliği } \\
\text { - Mevcut elektrik altyapısında } \\
\text { yenilenebilir penetrasyonunun düşük } \\
\text { olması ve eskiyen ekipmanlar olması } \\
\text { - Müşterilerin piyasaya katılımında } \\
\text { engeller olması } \\
\text { - Düzenleme ve politikalarla ilgili } \\
\text { belirsizlikler } \\
\text { - Akıllı şebekelere geçiş büyük } \\
\text { yatırımlar gerektirdiği için }\end{array}$ \\
\hline
\end{tabular}




\begin{tabular}{|c|c|c|c|c|c|c|c|}
\hline & & & & & & $\begin{array}{l}\text { ve varlıkların yönetimi konusunda belirli bir } \\
\text { aşama kaydetmesi } \\
\text { - Değerlendirme ile ilgili çalıştaylar yapılması }\end{array}$ & karşılaşılan finansal zorluklar \\
\hline $\begin{array}{l}\text { Hindistan } \\
{[12]}\end{array}$ & Ülke & Talep katılımı & Evet & Hayır & (Geçerli Değil) & - Modelin ülkeye göre uyarlanması & $\begin{array}{l}\text { - Modelin değerlendirilmesi ile ilgili } \\
\text { pilot çalışma yapılmaması }\end{array}$ \\
\hline Avrupa [13] & Ülke & $\begin{array}{l}\text { Genel } \\
\text { değerlendirme }\end{array}$ & Evet & Evet & $\begin{array}{l}\text { Farklı } \\
\text { uzmanlar }\end{array}$ & 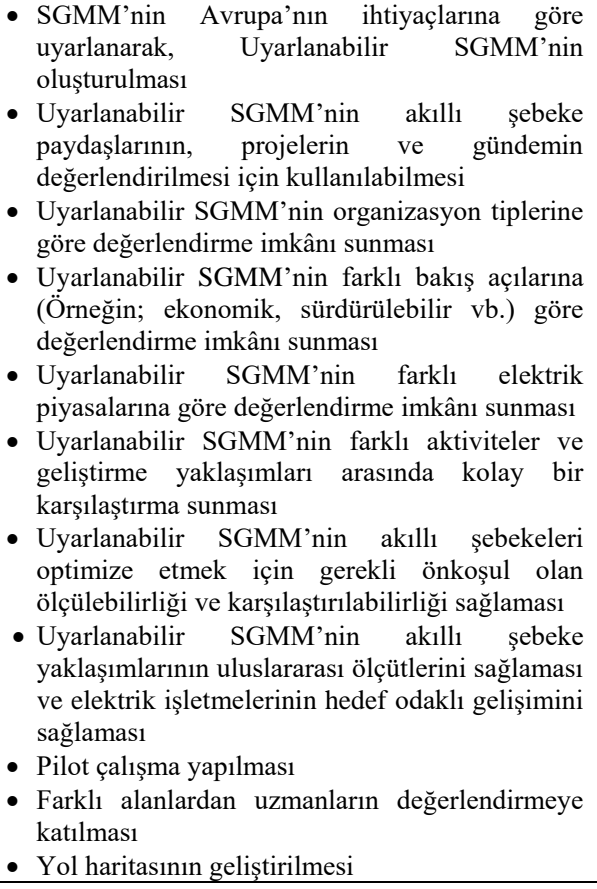 & $\begin{array}{l}\text { - SGMM'nin özel amaçlar için } \\
\text { doğrudan kullanılamaması } \\
\text { - SGMM'nin esas olarak elektrik } \\
\text { işletmelerine odaklanması } \\
\text { - SGMM'nin değerlendirme için ortak } \\
\text { bir yaklaşım sunması, soru anketinin } \\
\text { uyarlanamaması } \\
\text { - SGMM'nin Avrupa elektrik } \\
\text { piyasasına uygun olmaması } \\
\text { - SGMM değerlendirme sisteminin } \\
\text { herkese açı olmaması } \\
\text { - SGMM olgunluk seviyelerine } \\
\text { bakıldığında alt seviyedeki tüm } \\
\text { karakteristikler yerine getirilmeden, } \\
\text { bir üst seviyedeki karakteristiklerin } \\
\text { çoğunluğunun yerine getirilebilir } \\
\text { olması } \\
\text { - SGMM'de bir alana ait olgunluk } \\
\text { seviyeleri kriterlerinin alanın } \\
\text { kendisiyle tutarsız olması }\end{array}$ \\
\hline $\begin{array}{l}\text { Umman } \\
{[14]}\end{array}$ & Ülke & $\begin{array}{l}\text { - Talep tarafi } \\
\text { yönetimi } \\
\text { - Enerji } \\
\text { verimliliği } \\
\text { - Dağıtık } \\
\text { üretim }\end{array}$ & Evet & Evet & $\begin{array}{l}\text { - Sultan } \\
\text { Üniversitesi } \\
\text { - Umman Araboos } \\
\text { Konseyi }\end{array}$ & $\begin{array}{l}\text { - Strateji geliştirirken SGMM } \\
\text { seviyelerinden faydalanarak } \\
\text { oluşturulması senaryolar } \\
\text { - Senaryolar için belirli bir metodoloji } \\
\text { kullanılması } \\
\text { - Oluşturulan olgunluk senaryolarına göre fayda- } \\
\text { maliyet analizlerinin sunulması } \\
\text { - Yapılacak analizlerde farklı santrallerden gerçek } \\
\text { üretim verisinin alınması } \\
\text { - Çalışmaların Hükümet tarafından yapılması }\end{array}$ & $\begin{array}{l}\text { - DSM uygulanması için ciddiyet } \\
\text { eksikliği }\end{array}$ \\
\hline
\end{tabular}


Türkiye'de SGMM kullanımı ile ilgili bir çalışma olmamakla birlikte, Türkiye 2023 Akıllı Şebekeler Yol Haritası'nın uygulamaları bu model uyarlanarak değerlendirilebilir. Bu sebeple, SGMM'nin Türkiye'de uyarlanmasının güçlü ve zayıf yönleri ile firsat ve tehditlerin neler olabileceği Tablo 7'de analiz edilmiştir. $\mathrm{Bu}$ değerlendirmeye göre; SGMM TAŞ23'te belirlenen hedeflerin yerine getirilmesi için yol haritasının uygulanmasına yardımcı olabilir, yatırım yapılması gereken alanlara yönlendirebilir ve gerekli mevzuat düzenlemeleri için yol gösterebilir. Ancak, SGMM değerlendirme anketindeki puanlandırma yönteminin açık olmaması ve öz-değerlendirmeyi desteklememesi modelin uyarlanmasını zorlaştırmaktadır. Ayrıca Türkiye'de toplam kalite anlayışının henüz olgunlaşmamış olması da SGMM'nin uyarlanmasını kısıtlayıcı bir etkendir.

$\mathrm{Bu}$ bağlamda öncelikle, olgunluk modelinin faydaları hakkında bilinçlendirmeye ihtiyaç bulunmaktadır. Akıllı şebekelere geçiş için mevzuat altyapısının ve AR-GE sistematiğinin olgunlaştırılması gerekmektedir. Sonrasında akıllı şebeke yol haritası hedeflerinin izlenmesi ve geçiş süreci yönetimi için, öz-değerlendirme imkânı sağlayan ve yol gösterici bir olgunluk modeli geliştirilerek kullanılmalıdır.

Tablo 7. SGMM'nin Türkiye için uyarlanmasına yönelik SWOT analizi

(SWOT analysis for adaptation of SGMM in Turkey)

\begin{tabular}{|c|c|}
\hline Güçlü Yönler & $\begin{array}{l}\text { - TASS23'te belirlenen yol haritasının amaçlarının uygulanmasına yardım edecek yeteneğe sahiptir. } \\
\text { - TAŞ23 hedeflerinin gerçekleştirilmesi için uygulanacak süreçlerin değerlendirilmesini sağlayacak } \\
\text { yeteneğe sahiptir. } \\
\text { - Türkiye'nin teknolojik değişim ve yenilikçilik haritasında yol gösterecek niteliktedir. }\end{array}$ \\
\hline Zayıf Yönler & $\begin{array}{l}\text { - Sadece sertifikalı değerlendiriciler tarafından değerlendirme yapılabilmesi herkes tarafından kullanımı } \\
\text { kısıtlar. } \\
\text { - Değerlendirme anketindeki puanlandırma yönteminin herkese açık olmaması öz-değerlendirmeyi } \\
\text { engeller. }\end{array}$ \\
\hline Firsatlar & $\begin{array}{l}\text { - Türkiye'nin TAŞ23 planlarının gerçekleştirilmesi için gerekli mevzuat düzenlemeleri ve geliştirilmesi } \\
\text { gereken iş modelleri için yol gösterir. } \\
\text { - Akıllı şebeke için yatırım yapılması gereken alanlara yönlendirir ve doğru yatırıma teşvik eder. } \\
\text { - Artan yenilenebilir enerji kaynaklarının şebekeye entegrasyonunu kolaylaştırıcı değerlendirmeler sunar. }\end{array}$ \\
\hline Tehditler & $\begin{array}{l}\text { - Mevzuatta akıllı şebekeler için düzenleme/teşvik yeterli değildir. } \\
\text { - Mevcut AR-GE sistematiği yeterli değildir. } \\
\text { - Mevcut kalite anlayışı, olgunluk modeli kullanımına yönlendirmez. }\end{array}$ \\
\hline
\end{tabular}

\section{SONUÇ (CONCLUSION)}

$\mathrm{Bu}$ çalışma ile akıllı şebeke alanında olgunluk modeli olarak önerilen SGMM anlatılmış, literatürdeki SGMM uygulamaları araştırılmıştır. SGMM'yi doğrudan kullanan bir çalışma bulunamamış, ancak SGMM'yi uyarlayarak kullanan ülke ve bölge çalışmaları incelenmiştir. Literatür taraması sonucunda tespit edilen uyarlamaların azlığı bu alanda yapılan çalışmaların sınırlı olduğunu göstermektedir. İncelenen çalışmalar, SGMM'nin kurumların mevcut olgunluklarını tespit etmede ve hedeflerine ulaşmak için yapılması gereken pratikleri belirlemesinde yardımcı olduğunu göstermektedir. $\mathrm{Bu}$ faydalar açık olmakla birlikte, SGMM'nin uyarlanarak kullanılması sırasında bazı kritik dezavantajlar ortaya çıkmaktadır.

$\mathrm{Bu}$ dezavantajlardan ilki, sadece sertifikalı değerlendiricinin SGMM anketini ve ilgili çalıştayları gerçekleştirmek için nitelikli sayılmasıdır. İkinci olarak, SGMM'nin sektördeki rollere (dağıtım şirketi, iletim şirketi, üretim şirketi vb.) göre pratikler belirlememiş olması ve farklı ülkelerin elektrik piyasa yapılarına göre uyarlanabilir olmaması, modelin kullanımını zorlaştırmaktadır. Üçüncü olarak, değerlendirmede kullanılan puanlandırma yönteminin açık olmaması, modelin herkes tarafindan kullanımını engellemektedir. Dördüncü dezavantaj ise SGMM'nin olgunluk seviyelerine bakıldığında alt seviyedeki tüm özellikler yerine getirilmeden, bir üst seviyedeki özelliklerin çoğunluğunun yerine getirilebiliyor olmasıdır. $\mathrm{Bu}$ dezavantajlardan dolayı SGMM'nin doğrudan kullanılamadığı, başka modellerle birleştirilerek veya uyarlama yapılarak kullanılabildiği incelenen çalışmalarda görülmektedir.

SGMM'nin uyarlanarak kullanımı üzerine yazarlar tarafindan yapılan bu değerlendirme; sektördeki rollere göre pratiklerin özelleştiği, farklı piyasa yapılarına göre uyarlanabilir, puanlandırma şekli ve kriterleri açık olan, herkes tarafından kullanılabilir ve olgunluk seviyeleri arasındaki kademeli geçişin alt-üst seviye ilişkisini gözeterek tanımlandığı bir model ihtiyacını ortaya koymaktadır. Bu hususları dikkate alarak geliştirilecek bir modelin daha kullanılabilir bir kılavuz olacağı ve kurumların akıllı şebeke hedeflerine ulaşmasını kolaylaştıracağı değerlendirilmektedir. Bu özellikleri 
sağlayacak bir modelin SGMM'in zayıf yönlerini bertaraf ederek akıllı şebeke arayışlarını hızlandırabileceği ve Türkiye için de temel bir çerçeve sunarak mevcut çalışmaların düzeyini ölçmede ve iyileştirmede önemli bir kıyaslama mekanizması olabileceği değerlendirilmektedir.

\section{KAYNAKLAR (REFERENCES)}

[1] M. E. El Hawary, "The smart grid--state-of-the-art and future trends", Electric Power Components and Systems, 42(3-4), 239250, 2014.

[2] M. Shabanzadeh, M. Moghaddam, "What is the smart grid? definitions, perspectives, and ultimate goals", 28th International Power System Conference (PSC), Tahran, 2013.

[3] M. Nassar, A. Dabak, I. H. Kim, T. Pande, B. L. Evans, "Cyclostationary noise modeling in narrowband powerline communication for Smart Grid applications", IEEE International Conference on Acoustics, Speech and Signal Processing (ICASSP), Japan, 3089-3092, 2012.

[4] M. McGranaghan, D. Von Dallen, P. Myrda, E. Gunther, "Utility experience with developing a smart grid roadmap", Power and Energy Society General Meeting-Conversion and Delivery of Electrical Energy in the 21st Century IEEE, USA, 1-5, 2008.

[5] Software Engineering Institute- Carnegie Mellon University (SEI-CMU), "Smart Grid Maturity Model (SGMM)", http://www.sei.cmu.edu/smartgrid, USA, 2011.

[6] A. Singhal, R. P. Saxena, "Software models for smart grid", Proceedings of the First International Workshop on Software Engineering Challenges for the Smart Grid, IEEE Press, Zurich, 42-25, 2012.

[7] A. Aldana, R. Cespedes, E. Parra, R. Lopez, M. E. Ruiz, "Implementation of smart grids in the Colombian electrical sector", Innovative Smart Grid Technologies (ISGT Latin America), IEEE PES Conference on, Colombia, 1-6, 2011.

[8] National Institute of Standards and Technology (NIST), "NIST Framework and Roadmap for Smart Grid Interoperability Standards", U.S. Department of Commerce (U.S. DoC), 2010.
[9] F. Mejia, R. Glasberg, G. Tamm, G. J. Lopez. "Readiness level to adopt smart grid technologies-Study for the city of Medellin”, Innovative Smart Grid Technologies (ISGT Latin America), 2011 IEEE PES Conference on, Colombia, 1-7, 2011.

[10] D. N. Y. Mah, Y. Y. Wu, J. C. M. Ip, P. R. Hills, "The role of the state in sustainable energy transitions: A case study of large smart grid demonstration projects in Japan", Energy Policy, 63, 726-737, 2013.

[11] Y. Liao, M. Turner, Y. Du, "Development of a smart grid roadmap for Kentucky", Electric Power Components and Systems, 42(3-4), 267-279, 2014.

[12] H. Endow, M. Triplett, "Demand response-The maturity cycle", Innovative Smart Grid Technologies-Asia (ISGT Asia), IEEE, China, 2013.

[13] S. Rohjans, M. Uslar, A. Cleven, R. Winter, F. Wortmann, "Towards an adaptive maturity model for smart grids", Proceedings of the 17th Power Systems Computation Conference (PSCC), Stokholm, 2011.

[14] S. Malik Arif, M. Albadi, M. Al-Jabri, A. Bani-Araba, A. AlAmeri, A. Al Shehhi, "Smart grid scenarios and their impact on strategic plan-A case study of Omani power sector", Sustainable Cities and Society, 37, 213-221, 2018.

[15] Internet: Enerji ve Tabii Kaynaklar Bakanlı̆̆ 1 (ETKB), Enerji Verimliliği Strateji Belgesi (2012-2023), http://www.resmigazete.gov.tr/eskiler/2012/02/20120225-7.htm, 10.01.2019

[16] Internet: Enerji ve Tabii Kaynaklar Bakanlığı (ETKB), Ulusal Enerji Verimliliği Eylem Planı (2017-2023), https://www.enerji.gov.tr/tr-TR/Sayfalar/Ulusal-EnerjiVerimliligi-Eylem-Plani,10.01.2019.

[17] Internet: Türkiye Elektrik İletim A.Ş. (TEİAŞ), 2015-2019 Dönemi TEİAŞ Stratejik Planı, https://www.teias.gov.tr/sites/default/files/201806/TE\%C4\%B0A \%C5\%9E\%20Stratejik\%20Plan\%202015-2019.pdf, 26.12.2018.

[18] Internet: Elektrik Dağıtım Hizmetleri Derneği (ELDER), Türkiye 2023 Ak1llı Şebekeler Yol Haritası, https://www.akillisebekelerturkiye.org, 5.11.2018. 